\title{
CREATION OF STUDY MATERIAL FOR ADPTIVE E-LEARNING
}

\section{Blanka CZECZOTKOVÁ - Tatiana PREXTOVÁ}

\begin{abstract}
Paper deals with teaching methods and teaching styles of teachers, which can be used in creation of adaptive learning material. Study materials are embedded into elctronic adaptive learning. Adaptive learning program is controled by a learning management system - a virtual teacher. The essence of the virtual teacher is as follows. Based on assessed individual learning mode of student virtual teacher suggests the most suitable study material. Virtual teacher consists of vast database of various learning modes, student charachteristics and rules for creation of adaptive study materials. Aim of this paper is use of teaching methods and teaching styles which are then used by virtual teacher for teaching each individual. Learning in this adaptive form of education is getting more efficient and rewarding. Knowledge and skills gained during this process is tested adaptively too.
\end{abstract}

Keywords: virtual teacher, teaching methods, teaching styles, optimal learning mode, adaptive testing.

\section{TVORBA STUDIJNÍ OPORY PRO ADAPTIVNÍ VÝUKU}

Resumé: Příspěvek pojednává o vyučovacích metodách a vyučovacích stylech učitelů, které lze uplatnit při tvorbě adaptivního studijního materiálu. Studijní materiály jsou zakomponovány do elektronické adaptivní výuky. Adaptivní výuku řídí programový systém pro řízení výuky - virtuální učitel. Podstata virtuálního učitele je následující. Na základě zjištěného individuálního učebního stylu studenta mu virtuální učitel předloží nejvhodnější studijní oporu. Virtuální učitel obsahuje rozsáhlou databázi různých stylů učení, vlastností studentů a pravidla pro tvorbu adaptivních studijních materiálů. Cílem příspěvku je využití vyučovacích metod a vyučovacích stylů učitelů, které virtuální učitel aplikuje při učení jednotlivého studenta. Učení se touto adaptivní formou výuky stává pro studenta efektivnější a přínosnější. Nabyté vědomostí a znalosti se adaptivně otestují.

Klíčová slova: virtuální učitel, vyučovací metody, vyučovací styl učitele, optimální výukový styl, adaptivní testování. 


\section{1 Úvod}

Informační a komunikační technologie jsou neodmyslitelnou součástí dnešní doby a denně se s nimi setkáváme. Ve výuce už nevystačíme pouze s tabulí a křídou. Jestliže chceme studenta zaujmout a výuku obohatit o inovační prvky, zvolíme technologii ze široké nabídky, kterou disponují ICT.

Na všech typech škol se dostává do popředí e-learningová výuka, jejíž hlavní ideou je, že počítač dokáže prezentovat informace, zobrazovat je odlišnými způsoby a veškerou činnost, kterou vykonaná student protokolovat. Mezi další priority LMS patří bezesporu snadná modifikovatelnost elektronických studijních materiálů, možnost zakomponování multimediálních a interaktivních prvků $v$ elektronických studijních materiálech a zpětná vazba.

Výuka vedena pomocí e-learningu má mnoho výhod. Výuka však nebere $\mathrm{v}$ potaz studenta jako hlavní prvek učebního procesu. Každý student je individualita a má jiný učební styl, podle kterého se mu studuje nejlépe, nejefektivněji a nejekonomičtěji.

Výuka, která akceptuje individuální učební vlastnosti studenta, nazýváme adaptivní e-learningovou výukou. Tato výuka musí obsahovat studijní materiály pro různé typy studentů.

Optimální adaptivní učební proces respektuje individuální učební styly studentů, které jsou získané ze vstupního dotazníku před zahájením výuky. Na základě těchto informací předloží virtuální učitel studentovi studijní materiál $\mathrm{v}$ podobě, který mu nejvíce vyhovuje. Studentovy nabyté vědomostí a znalostí se adaptivně otestují.

\section{Model výuky pro adaptivní e- learning}

Adaptivní model e-elarningové výuky se skládá ze 3 částí:

Modul Student - před každým začátkem učebního procesu se student otestuje a identifikuje se jeho učební styl. Více informací v publikacích K. Kostolányová [5].

Modul Autor - jedná se o autorskou databázi, která zahrnuje výukové texty a multimédia - jednotlivé obrázky, flash animace, atd. a metadata.

Modul Virtutální učitel - ten vytvoří na základě znalosti učebního stylu studenta, konkrétní výukové opory, vyučovací metody a vyučovacího stylu učitele optimální způsob výuky, kterým bude studenta vyučovat. Tento způsob výuky je měnitelný a student si může výuku ř́́dit i sám.

\section{Vyučovací styl učitele}

$\mathrm{V}$ běžné pedagogické praxi se můžeme setkat se dvěma úhly pohledu na vyučovací styly učitelů. Zaprvé vyučovací styl chápeme jako způsob vyučování učitele, tj. jak vyučuje, a druhý úhel pohledu 
je užší a je J. Průchou, E. Walterovou a J. Marešem [9] definován jako „svébytný postup učitele, který učitel uplatňuje ve vyučování, který používá ve většině situací pedagogického typu nezávisle na okolnostech. Je to styl relativně stabilní a obtížně se měni".

Vyučovacími styly a typologiemi dle různých hledisek se zabývalo mnoho odborníků.

Typologií dělíme dle různých kritérií:

- podle osobnosti pedagoga (C. G. Jung, H. J. Eysenck, R. B. Cattela,...),

- podle působení ve škole (J. Štá$\mathrm{gl}, \ldots)$,

- podle pedagogického působení (Ch. Caselmann,...),

- podle stylu výchovy (K. Lewin, R. Lippitt, R. K. White, R. a A. M. Tausch, C. Rogers, H. H. Anderson,...),

- podle propojení pedagogické osobnosti s pedagogickým působením (M. Brekelmans, H. Créton, J. Levy, R. Rodriguez, T. Wubbels, T. Leary,...),

- podle komunikačního stylu (M. Brekelmans, J. Levy, R. Rodriguez,...),

- podle reakcí na podněty (E. Luk), - atd.

Při rešerši vyučovacích stylů učitelů jsme došly $\mathrm{k}$ závěru, že nejefektivnější způsob seskupení vyučovacích stylů učitelů je seskupit je podle jejich totožných charakteristických rysů v jeden vyučovací styl. Vyučovací styly učitelů jsme seskupily dle jejich charakteristik, synonym názvi̊, autorů, kteří se daným vyučovacím styl zabývali, a ke každému vyučovacímu stylu jsme odvodily definice.

Jako ukázku uvádíme členění podle stylu vedení výuky:

1. Autokratický styl (autoritativní, dominantní, diktátorský, autoritářský, mocenský, direktivní, manažerský, rrídící, represivní, vyučovatelský) tímto vyučovacím stylem se zabývali K. Lewin, R. Lippit, R. K. White, N. A. Flanders, Ch. Caselmann, T. Leary, J. Levy, R. L. La Forge, R. F. Suczek, H. H. Anderson, G. D. Fenstermacher, J. F. Soltis, Z. Zaborowski, M. Brekelmansová, T. Wubbels, R. Rodriguezová, Marchand, H. A. Creton, H. P. Hoomayers W. O. Döring.

„Učitelé, kteři uči autokratickým stylem, jsou pro studenty autoritou. $V$ praxi se můžeme setkat s jevem, že studenti vnímaji tohoto učitele bud' jako prirozenou autoritu nebo jej vnímaji jako učitele „tyrana“ a respektuji ho ze strachu.

Mezi charakteristické vlastnosti učitelé patři nařizování, rozhodování, kontrolování a dokážou ve tř́idě udržet disciplínu. Předávají srozumitelně výklad, metodické postupy jsou pečlivě zpracovány. Učitel jedná formou př́kazů a o všem rozhoduje sám. Studenti se aktivně výuky neúčastní, mají malý prostor pro samostatné jed- 
nání a rozhodování, na základě čehož dochází k útlumu jejich iniciativy. Ve výuce chybí prostor pro diskusi, individuální rozvoj osobnosti studenta.

Učitel má malé pochopení pro studenty, jejich potřeby, individuální odlišnosti, není schopen empatie, navic nebere v úvahu žádné jejich připomínky (návrhy, náměty).

$V$ mnoha prípadech dokonce učitel zesměšňuje studenty pred ostatními $v$ jejich prípadném neúspěchu či problému. To může vést $k$ tomu, že studentovi sniži sebevědomí, vyvolá $v$ něm pocit méněcennosti. Soustavné ponižování může $v$ nejhorším připadě vést ke strachu ze školního prostředí (především jeho vyučovací hodina). " [1]

2. Demokratický styl (integrační, sociálně-integrační, kooperativní, sociální, tolerantníautokratický, interaktivní, facilitační, nedirektivní, supervizorský) tímto vyučovacím stylem se zabývali Ch. Caselmann, W. O. Döring, M. Brekelmansová, N. A. Flanders, J. Levy, R. Rodriguezová, T. Wubbels,Z. Zaborowski, G. D. Fenstermacher, J. F. Soltis, D. G. Ryans, H. H. Anderson, K. Lewin, R. Lippit, R. K. White.

„Učitel, který méně přikazuje, rozhoduje a řídí studenty, než u stylu autokratického. Učitel má mnohem větši přehled o přáních a potřbách studentü, o jejich individualitě a má pro ně větši pochopení. Učitel uprednostňuje samo- statnost, dobrovolnou spolupráci a úsudek studentů. Ve třídě panuje príznivá atmosféra, která pomáhá rozvijet sociálně zralou osobnost studenta. Studenti jsou podněcováni k samostatné činnosti a je u nich podporována iniciativa. " [1]

3. Liberální styl (Laissezfaire, nezasahující, nejistý-toleratní, pragmatický) tímto vyučovacím stylem se zabývali Z. Zaborowski, G. D. Fenstermacher, J. F. Soltis, K. Lewin, R. Lippit, R. K. White, M. Brekelmansová, J. Levy, T. Wubbels, H. A. Creton, H. P. Hoomayers, R. Rodriguezová, T. Wubbels, A. W. Aleck.

„Nejistě, lhostejně $k$ okolí, stěžováním si na své osobní problémy, takto lze popsat učitele vyučujicího liberálním stylem. $\mathrm{Na}$ studenty nejsou kladeny téměr žádné požadavky. Studenti jsou charakterizování nízkým výkonem, soustřed'ují se na v̌̌e ostatní, jen ne na výuku, což se jeví jako chaotická výuka.

Studenti mivaji nedostatečné vědomosti, znalosti a dovednosti, neplní zadané úkoly ani domácí práce. Vědí totiž, že za neplnění úkolů nemají žádný postih. Nejsou dostatečně motivováni, což má za následek, že aktivní jsou pouze jedinci, kteří si sami kladou své cíle. Ostatní spolužáci je vnímají jako „šprty, hujery“. Učitel tak nechtě ovlivňuje negativní klima ve třídè. " [1].

Mezi mnoha klasifikacemi můžeme rozeznat překrývající se typy, 
někdy jen jinak pojmenované. I když obvykle charakteristiky typů nejsou formulovány totožně a bylo by možné mezi nimi rozpoznat menší rozdíly, popisují v podstatě podobný typ.

Po celkové eliminaci vyučovacích stylů jsme, pojmenovaly hlediska klasifikací a rozdělily je podle uvedených typů vyučovacích stylů:

- Podle př́stupu ke studentům: autokratický, demokratický, delegátor, psychologický,

- Podle přístupu k výkladu látky: teoretický, praktický, ekonomický

- Podle přístupu k novinkám odborným, pedagogickým.

- Podle prŕístupu k profesi učitele.

Pro adaptivní výuku nepoužijeme poslední dvě hlediska. U virtuálního učitele řídicího adaptivní elearningovou výuku předpokládáme profesionální vlastnosti. Z prvních dvou hledisek také nebereme v úvahu typy pro výuku evidentně nevhodné, jako typy liberální, náboženské, reproduktivní, nespokojené, plačky, kverulanty, ignoranty, zběhy, podnikatele, tandemisty atd.

\section{Vyučovací metody}

V literatuře a odborných publikacích se setkáváme se dvěma označeními pro metody používané ve výuce, o výukové a vyučovací metody. Někteří autoři se přikládají $\mathrm{k}$ výukovým metodám jiní zase $\mathrm{k}$ vyučovacím. Rozdíl mezi nimi není žádný, jedná se pouze o jiné pojmenování stejných metod.

Nejpodrobněji vyučovací metodu definoval L. Mojžíšek [6], definoval ji jako ,pedagogicky - specifickou didaktickou aktivitu subjektu a objektu vyučování, rozvijejicí vzdělanostní profil žáka, současně pưsobicí výchovnè, a to ve smyslu vzdělávacích a také výchovných cílù $a v$ souladu $s$ vyučovacími a výchovnými principy. Spočivá $v$ úpravě obsahu, v usměrnění aktivity objektu a subjektu, v úpravě zdrojů poznání, postupů a technik, $v$ zajištěni fixace nebo kontroly védomostí a dovedností, poznávacích procesů, zájmu a postojü. “ $\mathrm{Z}$ této definice jsme vycházely.

$\mathrm{V}$ současné době si na své přicházejí inovativní vyučovací metody, mezi něž patří diskusní metody, situační metody, inscenační metody, didaktické hry, heuristické metody, výuka dramatem, metody kritického myšlení,... Inovativním metodám je věnována řada studií (J. Dewey, W. Okón, G. Polya, A. M. Mat'uškin, I. Turek, B. S. Stein, J. Maňák, I. Lokšová a J. Lokša, T. Kotyrba a L. Lacina, T. Zat'ková a další).

Student ve výše uvedených vyučovacích metodách je ve výuce činorodým činitelem celého učebního procesu, ve většině případů se učí samostatným objevováním, aktivně komunikuje se spolužáky, učí se týmové práci, kooperaci atd. 
V současné době není do adaptivního e-learningu zakomponována většina inovativních metod, ale $\mathrm{v}$ budoucnu se s touto možností počítá.

„Mezi nejznáméjší pedagogy, kteři se zabývali rozdělením vyučovacích metod, jmenujme G. A. Lidner, S. Vrána, E. Stračár, L. Mojžíšek, D. O. Lordkipanidze, Z. Pešek, I. J. Lerner, M. Kořínek, J. Maňák, M. A. Danilov, B. P. Jesipov, $O$. Kádner, J. Hendrich, I. A. Kairov, A. Vališová, J. Valenta, E. J. Golant, J. I. Perovskij, B. R. Joyce, E. F. Calhounová...". [2]

$\mathrm{Na}$ vyučovací metody můžeme pohlížet také $\mathrm{z}$ různých hledisek $\mathrm{z}$ hlediska psychologického, procesuálního, z hlediska fáze výuky, $\mathrm{z}$ aspektu logického, organizačního nebo dle charakteru zdroje informací.

Stejně jako tomu bylo u vyučovacích stylů učitelů i zde vyplynulo, že někteři autoři vytvořili své členění vyučovacích metod, jiní autoři vycházeli ze svých předchůdců nebo v některých př́ípadech použili totožné členění, kdy došlo jen k záměně pořadí slov.

I vyučovací metody jsme seskupily podle aspektu klasifikace, synonym názvů a autorů, kteří se vyučovacími metodami zabývali.

Jako ukázku uvádíme vyučovací metody podle charakteru zdroje informací.

Metody podle charakteru zdroje informací (aspektu prame- ne, pramene poznání, teoretickopraktické roviny, podle sdělování poznatků) uvádí D. O. Lordkipanidze, E. Stračár, M. Kořínek, Z. Pešek, E. J. Golant, V. Švec, J. Maňák, A. Vališová a J. Valenta, O. Kádner, M. A. Danilov a B. P. Jesipov, Z. Pešek, J. Velikanič, J. Maňák, I. Turek, D. Sitná.

1. Metody slovní

a) dialogické - beseda, rozhovor, diskuse, brainstorming, dramatizace, dialog, brainwriting, Sokratovská metoda, Heuristická metoda, snowballing, Buzz Groups, debata, Case Study, Role Play, Carousel, mentální mapování, Goldfish Bowl, seminár

b) monologické - přednáška, výklad, popis vyprávění, vysvětlování, vyvozování, instruktáž, žákovský referát

2. Metody písemné - písemná práce, písemné cvičení, kompozice, grafické práce

3. Metody knižní - samostudium pomocí knih, práce s knihou, s textovým materiálem, s elektronickým materiálem

4. Metody pozorování objektů (názorné) - pozorování obrazů, filmů, předmětů a jevů, předvádění modelů, pokusů, činností, demonstrace obrazů a předmětů, práce s obrazem, instruktáž, pokusy, statické demonstrace, dynamické projekce, exkurze, vy- 
cházka, exkurzní demonstrace, ilustrace

5. Metody praktické - technické a laboratorní práce, zkoušení s hodnocením, napodobování, produkční metody, pohybové a pracovní dovednosti, pracovní, grafické a výtvarné činnosti, myšlenkové úkoly objevného charakteru, coaching-mentoring, counseling

Dialogické metody spočívají ve vzájemné komunikaci mezi dvěma či více subjekty. V této fázi nepoužijeme do adaptivní výuky žádnou z metod dialogických. Do budoucna se počítá $s$ rozšířením LMS Barborka, tak aby byl systém schopen využívat i dialogické metody. Komunikační nástroje v LMS jsou dvojího typu, komunikace mezi spolužáky a komunikace $\mathrm{s}$ učitelem. Komunikační nástroje nejsou vytvořený pro virtuálního učitele.

Monologické metody použijeme všechny v adaptivním e-learningu, a to speciálně ve výkladové části učiva.

U písemných metod musíme brát velký ohled na formu a obsah. Písemná práce, písemná cvičení, kompozice, čtvrtletní a pololetní písemné práce nelze uplatnit v adaptivní výuce, zatím virtuální učitel neumí vyhodnotit obsah. Diktáty lze v adaptivní výuce lze použít, jedná se o přepis namluveného slova do textové podoby. Správnost psaného slova zkontrolu- je speciální program. Grafické práce rovněž lze uplatnit $\mathrm{v}$ adaptivní výuce, ale pouze reprodukční práce, pro které již existuje software nebo lze vytvořit software, který bude schopný vyhodnocovat stanové zadání virtuálního učitele. Reprodukční práce jsou takové práce, jejichž výsledky lze porovnat pomocí speciálně vytvořených programů, např. zápis do notové osnovy, narýsování čtverce, doplnění slov do vět atd.

Všechny metody knižní lze pro učení uplatnit $\mathrm{v}$ adaptivním elearningu.

- práce s knihou - tištěná verze (kniha, odborná učebnice, skripta, slovníky, encyklopedie,...),

- práce $s$ textovým materiálem tištěná verze (sborník, prezentace, časopisy, vlastní poznámky),

- práce s elektronickým materiálem - elektronická verze (články na internetu, elektronické časopisy).

Z metod pozorování objektů lze $\mathrm{v}$ adaptivním e-learningu uplatnit

- vizuální pomůcky (statická demonstrace - obrázky, schémata, mapy, diagramy, naskenované fotografie, grafy a dynamická projekce - film, flash animace, postupné zobrazování, instruktáž),

- auditivní pomůcky (zvukové záznamy - audionahrávky básní, poslech knih, četba $\mathrm{v}$ cizím jazyce), 
- audiovizuální pomůcky (spojení zvukového záznamu s obrazem - filmy, predměty a jevy, předvádění modelů, pokusů, činností),

- kybernetické pomůcky (programy pro počítače),

- multimediální a hypermediální pomůcky (virtuální - exkurze, vycházka, exkurzní demonstrace, pokusy).

Tvưrčí práce nelze většinou uplatnit, protože nelze vytvořit software, který by byl schopný vyhodnotit stanovené zadání virtuálním učitelem. Tvưrčí práce jsou takové práce, jejichž výsledky nelze porovnat žádným programem, např. malování obrazů, tvorba skic, atd.

Praktické metody lze natočit na kameru a v adaptivní výuce pustit, bud' ve výkladových vrstvách, nebo ve vrstvě motivační. $V$ př́ípadě, že bychom chtěli praktické metody použít v testovací vrstvě, musíme si uvědomit, jaké budou studentovy výstupy. Grafické metody a výtvarné činnosti lze $\mathrm{v}$ adaptivní výuce uplatnit. Tyto metody dělíme na metody reprodukční a tvůrčí a platí pro ně stejná pravidla, jaká byla uvedena výše. Pracovní činnosti, pracovní dovedností a laboratorní činnosti nelze $\mathrm{v}$ adaptivní výuce uplatnit, pokud se jedná bezprostředně o fyzickou činnost studenta, kterou virtuální učitel nedokáže vyhodnotit a posoudit. Nácvik pohybových dovedností ještě nelze $\mathrm{v}$ adaptivní výuce uplatnit, ale po- mocí SW jako Wii nebo Xbox dokáže kamera snímat pohyb a vyhodnocovat situaci, a tak v brzké době bude možnost $\mathrm{v}$ adaptivní výuce uplatnit i metodu nácviku pohybových dovedností.

\section{Výukové opory pro adaptivní výuku}

Výukové materiály jsou rozděleny na elementární části. Každá část je zpracována vícenásobně v následujících variantách:

- varianty dle formy výkladu pro jednotlivé typy smyslového vnímání (auditivní, vizuální, kinestetický a verbální),

- varianty dle hloubky výkladu pro různou míru podrobnosti výkladu učiva.

Autor každý dílčí výukový materiál (rámec), vytvoří ve 12 variantách (4 druhy smyslového vnímání a 3 hloubky v podání výkladu). Dále se rámec ještě dělí na dílčí vrstvy, vzájemně zaměnitelného pořadí podle taktiky učení se studenta.

Do jednotlivých vrstev je vložen upravený studijní text, podle výše uvedeného hlediska. Vrstvy dělíme na:

- výkladové - teoretická, sémantická, fixační, řešené př́íklady a praktická;

- testovací - otázky, úlohy a praktické úlohy;

- ostatní - cíle, motivační, navigační, literatura. 
Zopakujme, že po analýze pedagogických prvků je úkolem této práce zabezpečit, aby výuková opora pro adaptivní výuku a všechny její části byly zpracovány tak, aby $\mathrm{z}$ nich bylo možno sestavit oporu pro kterýkoliv typ studenta. Pokud autor opory dodrží takto zformulovaná doporučení (pravidla), výsledkem by byla opora schopná jakékoliv adaptace.

Prvním úkolem je vybrat vhodné prvky pro e-learning a určit, pro kterou část výukové opory jsou vhodné. Možnosti jsou, že prvek je vhodný:

- obecně pro celou oporu,

- pro některé smyslové varianty opory,

- pro některé hloubkové varianty opory,

- pro některé typy vrstev u všech variant,

- pro některé typy vrstev některých variant.

Při psaní studijní opory používáme činná slovesa z Bloomovy taxonomie, kterou modifikoval A. Churches do digitální podoby.

Každý smyslový typ preferuje jiná aktivní slovesa, která je tak vhodné v jeho studijním materiálu používat.

Názorná ukázka tvorby studijní opory pro smyslovou variantu auditivní.

\section{Auditivní smyslový typ}

Student preferující auditivní smyslový typ lépe reaguje na výklad látky, jsou-li v něm obsažena následující slova: „slyšet, akcent, alarmovat, bouřlivý, ječet, hovořit, hluk, hlasitý, oznámit, volat, harmonie, formulovat, konstatovat, naladit, dotazovat, doslech, výmluvný, diskutovat" [4].

OBECNĚ pro celý výukový materiál (auditivní varianty) platí:

\section{Výkladové vrstvy}

Studijní materiál musí obsahovat informace $\mathrm{v}$ ústní $\mathrm{i}$ písemné podobě.

Při tvorbě auditivních pomůcek je nutné dbát na kvalitní př́ípravu dostatečná kvalita nahrávek (bez šumu, praskání, slabá hlasitost).

Při nahrávání studijní opory doporučujeme dodržovat následující pravidla:

- oslovování posluchačů,

- prriměřená hlasitost projevu, ani př́liš hlasitě, ani př́liš potichu, střídání ztlumeného a zesíleného hlasu udržuje pozornost posluchačů, výklad nesmí být monotonní,

- správná intonace hlasu udržuje pozornost posluchačů, umožňuje odlišovat podstatné informace od nepodstatných informací,

- artikulace zabraňuje špatnému pochopení informací,

- stabilita hlasového projevu zvýší důvěryhodnost přednášeného slova,

- tempo řeči volte plynulé, dbejte na správné dýchání, volte přiměřené pauzy (před/po sdělení významné informace, při poskytnutí prostotu k zamyšlení), 
- používejte pestrost slov, synonyma, metafory,...

- věty volíme krátké, přímé, srozumitelné, můžete použít činné věty, které výklad zpestří,

- omezte negativní výrazy a ,slovní vsuvky“ (hmm, prostě, vlastně, jasné, tak,...),

- ve výkladu používejte př́íklady.

\section{Testovací vrstvy}

Zadání sloužící k testování studentů zadáváme v ústní podobě.

\section{Ostatní vrstvy}

Text je ztvárněny do ústní a písemné podoby.

PODROBNĚ pro jednotlivé vrstvy platí:

\section{Teoretická vrstva}

- obsah: jasně, výstižně, stručně podané teoretické informace (definice, lemmna, axiom, pravidlo, vzorec,...),

- forma: písemná a auditivní podoba.

\section{Sémantická vrstva}

- obsah: detailněji popsány informace, doplňující informace k vrstvě teoretické výkladu je podrobné vysvětlení - rozvinutější než v teoretické vrstvě,

- forma: auditivní, písemná a audiovizuální podoba,

- doporučené vyučovací metody:

- ústní/písemné výklad - jedná se o část celku, prezentování didaktické informace. Hlavním cílem je vysvětlování učiva (definice, lemma, vzorce, pravidla,...) v širším/podrobnějším pojetí,

- ústní popis - jedná se o písemné vysvětlování konkrétního jevu, předmětu či věci. Metoda je spojená s pozorováním (ukázkou) konkrétního jevu, předmětu či věci,

- metody pozorování - student se zaměřuje na konkrétní učební pomůcku (ukázku) či aktivitu, kterou učitel aplikoval do výuky

- auditivní pomůcky (zvukové záznamy - audionahrávky básní, poslech knih, četba v cizím jazyce),

- audiovizuální pomůcky (spojení zvukového záznamu s obrazem - filmy, předmětů a jevů, předvádění modelů, pokusů, činností),

- multimediální a hypermediální pomůcky (virtuální - exkurze, vycházka, exkurzní demonstrace, pokusy).

\section{Fixační vrstva}

- obsah: jinak zformulované informace, které jsou propojeny do širšího kontextu,

- forma: auditivní, písemná a audiovizuální podoba,

- doporučené vyučovací metody:

- ústní/písemný výklad,

- ústní popis,

- metody pozorování. 


\section{Řešené př́íklady}

- obsah: př́klady, které slouží studentovi jako návod/postup $\mathrm{k}$ řešení stanoveného prríkladu,

- forma: auditivní, písemná a vizuální podoba,

- doporučené vyučovací metody:

- metody pozorování,

- ústní/písemný výklad,

- ústní popis,

- instruktáž.

\section{Praktická vrstva}

- obsah: př́klady, které slouží studentovi jako „motivace“ k aplikaci nabytých vědomostí, znalostí a dovedností,

- forma: auditivní, písemná a vizuální podoba,

- doporučené vyučovací metody:

- metody pozorování,

- metody praktická

- ústní/písemný výklad,

- ústní popis.

Otázky, úlohy, praktické př́íklady

- obsah: jasně položené otázky, které testují znalostí studentů,

- forma zadání: písemná (testy), auditivní (diktáty), vizuální (neverbální test - mozaiky, vzory, situace, kategorie, skládanky, analogie), audiovizuální (hledání rozdílů se zvukovým komentářem) podoba,

- typy odpovědi: uzavřené otázky (dichotomické, s výběrem jedné odpovědi, s vícenásobným výběrem odpovědi, prriřazovací, uspořádávající), otevřené otázky (s vymezenou strukturou, struktura dána konvenci, doplňova- cí), speciální otázky (programy, které porovnávají originální řešení se studentovým výsledkem),

- forma odpovědi: písemná, auditivní a vizuální podoba,

- doporučené vyučovací metody:

- klasické písemné a grafické zkoušky (denní písemné úkoly, domácí práce, měsíční práce, klauzurní a státní práce),

- klasické výkonné zkoušky (referáty),

- přesné písemné a výkonové zkoušky (běžné a orientační testy a standardizované testy).

\section{Cíle}

- obsah: přesně stanovené a formulované cíle nebo rámce, kterých má být po výuce dosaženo,

- forma: písemná podoba,

- doporučené vyučovací metody: - písemný výklad.

\section{Motivační vrstva}

- obsah: motivující informace, praktické prríklady, které motivují nemotivované studenty,

- forma: auditivní, audiovizuální podoba,

- doporučené vyučovací metody:

- vyprávění

- metody pozorování,

- instruktáž.

\section{Navigační vrstva}

- obsah: informace, které řídí studenta během procesu výuky,

- forma: auditivní a písemná podoba, 
- doporučené vyučovací metody:

- instruktáž.

\section{Literatura}

- obsah: seznam odborné literatury,

forma: písemná podoba.

\section{Adaptivní testování}

Princip fungování adaptivního testování je následující. Úlohy (praktické úlohy a teoretické otázky) se tvoří ve třech úrovních lehké (jednoduché) - střední (průměrné) - těžké (složité). Vytvořené úlohy se uloží do adaptivního systému (banka úloh). Individuální úlohy mají různý stupeň náročnosti, podle kterého jsou úlohy dále členěny do jednotlivých kategorií. Každé zadání je upraveno podle preferující smyslové varianty studenta. Adaptivní systém každému studentovi vygeneruje zadání testu na střední úrovni. Jestliže je student $\mathrm{v}$ testu úspěšný, adaptivní systém mu nabídne úlohy $\mathrm{z}$ těžší kategorie. V opačném případě, když je student neúspěšný, adaptivní systém mu nabídne úlohy z lehčí kategorie. Protože každý student má jinou úroveň vědomostí a znalostí, bude při testování vypracovávat vlastní individuální test $\mathrm{z}$ testovacího okruhu.

Kde můžeme využít adaptivní testování? Při učení se nového učiva student přechází jednotlivými fázemi. V 1. fázi se obeznamuje s novou látkou, zjišt'uje strukturu textu, všímá si nadpisů, zvýrazně- ných pasáží. V 2. fázi se hlouběji ponoří do studijního materiálu, dělá si vlastní poznámky, podtrhává si důležité pasáže v textu. Následuje fáze opakování, kdy je studentovi předložený test. Vyhodnocení (zpětná vazba) však student dostane okamžitě po každé testovací otázce (jestli je odpověd' správná/nesprávná, odkaz na studijní oporu, kde se dozví více o dané problematice). Takto prochází postupně celým testem a zjišt'uje, co umí, resp. co ještě neumí. Poslední fáze má název autotestování. I v této fázi je studentovi předložený test, který však vyplňuje plynule a zpětná vazba se mu zobrazí až na konci celého testu. A právě v posledních dvou režimech - opakování a autotestování - můžeme využit adaptivní elektronické testování.

Začlenění adaptivního testování by mělo pozitivně ovlivňovat psychiku studenta. Výběr testovacích úloh je přizpůsobený studentovým vědomostem a znalostem, proto by měl odpadnout strach $\mathrm{z}$ neúspěchu, že nebude schopný vyřrešit ani jednu testovací úlohu. Adaptivní testování se přizpůsobuje studentovi také v rychlosti řešení testu, kde na jednotlivou otázku má student dostatečné množství času $\mathrm{k}$ vyřešení zadané úlohy. Na základě dostatečného časového vyhranění odpadá strach $\mathrm{Z}$ nestihnutí vypracování testu.

Adaptivní testování probíhá ve dvou fázích. První fáze obsahuje 
dotazníkové šetření. Student vyplní dotazník, který se skládá ze tří částí - sociální faktory, školní prostředí a z učebního stylu studenta. V druhé fázi následuje samotné adaptivní testování, k jehož realizaci je zapotřebí vytvořit velkou množinu zadání úloh. $\mathrm{Na}$ základě formální klasifikace jsme roztř́idily zadání úloh na automaticky vyhodnotitelné a automaticky nevyhodnotitelné. Při kategorizaci úloh jsme vycházely z D. Tollingerové a vytvořily jsme obsahovou klasifikaci s pěti kategoriemi, které prezentují 5 stupňů náročnosti. V jednotlivých kategoriích je zadání úloh s různými možnostmi řešení určené pro konkrétní smyslové varianty.

Při tvorbě otázek vycházíme z následujícího členění:

Typy otázek pro ZNALOST:

- otevřené otázky - s vymezenou strukturou, struktura dána konvenci, doplňovací

- uzavřené otázky - dichotomické, s výběrem jedné odpovědi, $\mathrm{s}$ vícenásobným výběrem odpovědi, přiřazovací, uspořádávající

- speciální otázky - programy, které porovnávají originální řešení se studentovým výsledkem

Typy otázek pro DOVEDNOST:

- reprodukční - otevřené odpovědi, speciální odpovědi.

\section{Závěr}

Příspěvek pojednává o adaptivní výuce. $V$ první části příspěvku jsme se zabývaly adaptivním modelem výuky, který se skládá ze 3 částí modul Student, modul Autor a modul Virtuální učitel. V kapitole vyučovací styly jsme shromáždily jednotlivé vyučovací styly a použily jejich charakteristické vlastností, které lze zakomponovat do adaptivní výuky. Totéž jsme provedly s vyučovacími metodami a použitelné vyučovací metody zakomponovaly do adaptivního e-learningu. $\mathrm{V}$ páté kapitole byla podrobně popsána metodika pro tvorbu výukových adaptivních materiálu pro studenty upřednostňující auditivní smyslový typ při učení. $\mathrm{V}$ poslední šesté kapitole jsme popsaly princip a smysl adaptivního testování vědomostí a znalostí.

\section{Literatura}

[1] CZECZOTKOVÁ, B., KOSTOLÁNYOVÁ, K., ŠARMANOVÁ, J., Analysis of Teaching Styles of Teachers in the Contex of Elearning. Information and Communication Technology in Education. Ostrava: Ostravská univerzita, 2010. s. 111-115. [2010]. ISBN 978-80-7368-775-5

[2] CZECZOTKOVÁ B., KOSTOLÁNYOVÁ, K., ŠARMANOVÁ, J. The Optimal Teaching Style based on Variability of Study Materials. Brigthon Business School, University of Brighton: Academic Publishing Limited, 2011. s. 145-152. [2011]. ISBN 978-1-908272-23-2.

[3] CZECZOTKOVÁ, B., PREXTOVÁ, T. Teaching algorithm in 
adaptive e-learning. Teaching algorithm in adaptive e-learning. Atheny: GUIDE association, 2013. s. 1-10. [2013-10-03]. ISBN 9788897772026 [4] ČINKA, Libor. Ovládněte svioj mozek. Brno: BizBooks, 2012. ISBN 978-80-265-0022-3.

[5] KOSTOLÁNYOVÁ, Kateřina. Teorie adaptivního e-learningu. první. Ostrava: Ostravská univerzita v Ostravě, 2012. ISBN 978-807464-014-8

[6] MOJŽÍŠEK, L. Vyučovací metody. Praha: Státní pedagogické nakladatelství, n. p., 1988. 344. S [7] PREXTOVÁ, T., CZECZOTKOVÁ, B. Adaptive testing of student's knowledge level. Adaptive testing of student's knowledge level. Atheny: GUIDE association, 2013. s. 1-8. [2013-10-03]. ISBN 9788897772026

[8] PREXTOVÁ, T. Use of the Program Winsteps for Analyzing Test Tasks and Test Persons. Procedia - Social and Behavioral Sciences. 2012, s. 1077-1082.

[9] PRŮCHA, Jan; WALTEROVÁ, Eliška; MAREŠ, Jiří. Pedagogický slovník. Praha: Portál, 2001. 322 s. ISBN 80-7178-579-2
Mgr. Blanka Czeczotková Katedra informačních a komunikačních technologií, Pedagogická fakulta OU

Fr. Šrámka 3, 70903 Ostrava Tel: 597092631

E-mail:

Blanka.Czeczoktova@osu.cz

www pracoviště:

http://pdf.osu.cz/kik/

Mgr. Tatiana Prextová

Katedra informačních a komunikačních technologií, Pedagogická fakulta OU

Fr. Šrámka 3, 70903 Ostrava

Tel: 597092631

E-mail: Tatiana.Prextova@osu.cz www pracoviště:

http://pdf.osu.cz/kik/ 